\title{
Pengaruh fama-french five factor model terhadap excess return pada perusahaan LQ 45 tahun 2014-2019
}

\author{
Ervina Widyaningsih, Fadia Zen* \\ Universitas Negeri Malang, Jl. Semarang No. 5 Malang, Jawa Timur, Indonesia \\ *Penulis korespondensi, Surel: fadia.zen.fe@um.ac.id
}

Paper received: 3-5-2021; revised: 24-5-2021; accepted: 28-5-2021

\begin{abstract}
Abstrak
Penelitian ini bertujuan untuk mengetahui pengaruh masing-masing variabel Fama-French Five Factor Model yaitu premi risiko, ukuran perusahaan, book to market ratio, profitabilitas dan investasi terhadap Excess return pada perusahaan LQ 45 tahun 2014-2019. Terdapat 23 perusahaan yang terdaftar dalam indeks LQ 45 secara berturut-turut dari tahun 2014-2019 dari total 60 perusahaan yang terdaftar pada LQ 45 tahun 2014-2019 dengan menggunakan teknik pengambilan sampel purposive sampling. Penelitian ini adalah penelitian kuantitatif dengan menggunakan metode analisis regresi linear berganda. Hasil penelitian ini menunjukkan bahwa terdapat pengaruh yang signifikan antara premi risiko, ukuran perusahaan serta book to market ratio. Sedangkan untuk variabel profitabilitas dan investasi tidak berpengaruh terhadap Excess Return pada perusahaan LQ 45 tahun 2014-2019. Hasil penelitian juga menunjukkan bahwa variabel premi risiko, ukuran perusahaan, book to market ratio, profitabilitas serta investasi berpengaruh secara simultan terhadap excess return pada perusahaan LQ 45 tahun 2014-2019 yaitu sebesar 48,1\%. Disarankan untuk peneliti selanjutnya menggunakan variabel lain atau menambah variabel lain agar dapat menghasilkan nilai $R$ Square yang lebih besar atau lebih kuat, dan menguji model estimasi yang lain seperti CAPM atau APT.
\end{abstract}

Kata kunci: Fama-French Factor Model; Excess Return; Premi Risiko; Ukuran Perusahaan; Book to Market Ratio; Profitabilitas; Investasi

\section{Pendahuluan}

Pasar modal adalah tempat bertemunya pemilik modal dengan yang membutuhkan modal. Pasar modal adalah sarana bagi perusahaan untuk mendapatkan modal dari para investor dengan memperjualbelikan instrumen jangka panjang seperti saham dan obligasi (Bursa Efek Indonesia, 2020).

Menurut Undang-Undang No 8 tahun 1995, pasar modal memiliki peran dalam pembangunan nasional yaitu sebagai salah satu sumber pembiayaan perusahaan dan tempat untuk investasi bagi masyarakat. Dengan berinvestasi, investor mengharapkan akan mendapatkan tingkat pengembalian atau return yang tinggi dengan risiko yang rendah.

Salah satu surat jangka panjang yang diperjualbelikan di pasar modal adalah saham. Menurut Widiatmodjo (2004:54) saham adalah tanda penyertaan atau bukti kepemilikan seseorang atau badan dalam suatu perusahaan. Para pemegang saham akan mendapatkan pengembalian berupa return.

Return dan risiko tidak dapat dipisahkan. Return yang tinggi akan selalu diikuti dengan risiko yang tinggi pula. Oleh karena itu perlu dilakukan adanya estimasi dalam melakukan investasi saham. Terdapat beberapa model estimasi yang bisa lakukan.

This work is licensed under a Creative Commons Attribution-ShareAlike 4.0 International License. 
Salah satu metode yang cukup terkenal dalam menentukan return dan risiko sebuah portofolio adalah Capital Asset Pricing Model (CAPM) yang dikenalkan oleh Sharpe (1964) and Lintner (1969). Indikator yang digunakan dalam perumusan metode CAPM adalah beta pasar saham. Menurut Hanafi (2008:234) beta adalah ukuran kepekaan return terhadap perubahan pasar.

Model ini menemukan analisis hubungan antara return dan risiko yaitu bahwa semakin besar risiko suatu saham maka semakin besar pula return yang didapatkan atau dengan kata lain hubungan antara return dan risiko adalah positif.

Fama \& French (2001) menemukan bahwa tidak terdapat pengaruh antara beta terhadap return saham. Ashgarian dan Hansson (1998) dan Kumura, dkk (2000) juga menunjukkan hasil penelitian yang sama yaitu beta tidak berpengaruh terhadap return.

Beberapa peneliti banyak yang meragukan model ini dikarenakan hanya menggunakan satu indikator yaitu beta pasar saham sebagai penilaian return. Para peneliti ini beranggapan bahwa terdapat variabel lain yang mampu mempengaruhi tingkat pengembalian.

Salah satu penelitian yang menemukan variabel lain yang berpengaruh terhadap return adalah Basu (1977) menunjukkan variabel Price Earning Ratio (PER) berpengaruh terhadap return. Saham perusahaan yang memiliki rasio P/E yang rendah cenderung mempunyai return yang lebih tinggi dibandingkan saham perusahaan yang memiliki rasio $\mathrm{P} / \mathrm{E}$ tinggi.

Penelitian lainnya dilakukan oleh Banz (1981) menemukan size effect (ukuran perusahaan) berpengaruh terhadap return. Hasil penelitian menunjukkan bahwa return ratarata tahunan perusahaan yang tergolong kecil lebih besar dibandingkan dengan return ratarata tahunan perusahaan yang tergolong besar.

Fama dan French (1995) mengemukakan dua variabel lain yang mempengaruhi tingkat pengembalian yaitu size (ukuran perusahaan) dan book to market ratio. Penelitian ini dikenal dengan Fama-French Three Factor Model. Size dilihat dari nilai kapitalisasi pasar saham yang merupakan hasil kali dari harga saham dan jumlah saham yang beredar.

Pada tahun 2014, Fama-French menambahkan variabel lain yang dapat mempengaruhi tingkat pengembalian yaitu profitabilitas dan investasi. Model ini dikenal dengan Fama-French Five Factor Model. Hasil penelitian tersebut menemukan bahwa tingkat profitabilitas berbanding lurus dengan return. Sedangkan untuk investasi, perusahaan dengan total aset yang tinggi akan mendapatkan return yang rendah

Penelitian yang dilakukan oleh Acaravci dan Karaomer (2017) model ini mampu menjelaskan excess return pada saham yang terdaftar pada NYSE, AMEX dan NASDAQ pada periode 2012-2019. Penelitian yang dilakukan oleh Sutrisno (2016) yang menyatakan bahwa Fama-French Five Factor Model memiliki kemampuan lebih baik dalam menjelaskan excess return portofolio saham yang ada di Indonesia. Walaupun faktor profitabilitas dan investasi berpengaruh lemah terhadap excess return.

Zaremba \& Czapkiewicz (2017) membuat perbandingan analisis antara model CAPM, FFC4M, FF3F dan FF5F. Hasilnya yaitu Fama-French Five Factor Model memiliki keunggulan yang belum dimiliki oleh model sebelumnya, yaitu model ini bisa menjelaskan tentang 
portofolio excess return dan dapat menjelaskan anomali asset pricing. Temuan ini mendukung keunggulan dari Fama-French Five Factor Model.

Tetapi penelitian Munawaroh \& Sunarsih (2020) yang menunjukkan hasil yaitu variabel size tidak berpengaruh kuat terhadap excess return perusahaan yang terdaftar pada ISSI periode 2013-2017. Penelitian yang dilakukan Racicot dan Rentz (2016) menunjukkan bahwa HML atau book to market ratio tidak bersifat redundant. Begitupun dengan penelitian yang dilakukan oleh Ozkan (2018) menunjukkan hasil yang sama yaitu faktor HML tidak bersifat redundant pada perusahaan yang terdaftar di Istanbul Stock Exchange pada Juli 2009-Juni 2015.

Perbedaan hasil ini juga terjadi pada penelitian yang menggunakan perusahaan yang terdaftar pada indeks LQ 45 sebagai objek penelitiannya. Penelitian yang dilakukan Putra et al., (2019) terhadap excess return pada perusahaan LQ 45 menunjukkan bahwa semua variabel berpengaruh signifikan baik parsial maupun simultan terhadap excess return perusahaan LQ 45 pada periode $2014-2018$.

Djamaluddin dan Rofii (2017) juga melakukan penelitian Fama-French Five Factor Model terhadap perusahaan yang terdaftar pada indeks LQ 45 periode 2011-2015. Penelitian ini menunjukkan semua variabel berpengaruh terhadap terhadap return saham. Namun, penelitian yang dilakukan oleh Sudiyatno dan Irsyad (2011) menunjukkan bahwa variabel size dan book to market ratio tidak berpengaruh terhadap excess return.

Perbedaan hasil inilah yang menjadikan alasan mengapa penting dilakukan pengujian tentang Fama-French Five Factor Model terhadap excess return dan menguji apakah model ini juga bisa dijadikan acuan untuk investor dalam memilih saham dan apakah model ini menunjukkan hasil yang sama untuk objek penelitian yang sama namun untuk periode yang berbeda.

Pemilihan perusahaan LQ 45 sebagai obyek penelitian dikarenakan saham-saham yang terdaftar pada indeks LQ 45 adalah saham yang paling banyak diminati oleh para investor dikarenakan tingkat likuiditas dan nilai kapitalisasi pasar yang tinggi. Indeks saham LQ 45 juga memiliki karakteristik dan kinerja yang mewakili karakteristik dan kinerja IHSG (Indeks Harga Saham Gabungan).

Putra et al., (2019) melakukan pengujian Fama-French Five Factor Model pada indeks LQ 45 periode 2014-2018. Hasilnya adalah semua variabel berpengaruh signifikan baik parsial maupun simultan terhadap excess return perusahaan LQ 45 pada periode 20014-2018. Peneliti ingin mengetahui konsistensi dari model ini seandainya dalam periode ditambahkan satu tahun, apakah hasil penelitian menunjukkan hasil yang sama atau berbeda. Namun, dalam penelitian ini peneliti melakukan modifikasi dengan menggunakan penghitungan yang lebih sederhana bertujuan agar memudahkan para investor baru tetap bisa menggunakan metode Fama-French Five Factor Model.

\subsection{Konsep Return dan Risiko}

Return adalah reward bagi investor atas keberaniannya untuk menanggung risiko atas investasi yang dilakukan. Sumber-sumber return investasi adalah yield dan capital gain (loss). Yield adalah komponen return yang mencerminkan aliran kas atau pendapatan yang diperoleh 
secara periodik dari suatu investasi (Tandelilin, 2010:102). Dividen merupakan distribusi kas untuk para pemegang saham dari pendapatan perusahaan sebagai imbal hasil atas modal yang diinvestasikan (Besley dan Brigham, 2004:417). Dividen juga menunjukkan sebagai bentuk kesejahteraan yang diberikan kepada pemegang saham dari perusahaan.

Menurut Tandelilin (2010:102), risiko adalah perbedaan antara return aktual dengan return yang diharapkan. Semakin besar selisihnya, maka semakin besar risiko investasi yang dihadapinya. Dalam teori portofolio modern, risiko investasi total dapat dibedakan menjadi dua yaitu risiko sistematis dan risiko tidak sistematis. Risiko sistematis adalah risiko yang terjadi karena perubahan pasar. Oleh karena itu, risiko sistematis sering disebut juga risiko pasar.

Sedangkan risiko tidak sistematis adalah risiko yang tidak berkaitan dengan perubahan pasar. Risiko ini lebih terkait dengan keadaan mikro perusahaan penerbit sekuritas. Jadi risiko yang akan dialami setiap investor bisa jadi berbeda besarnya. Risiko tidak sistematis bisa diminimalkan dengan melakukan diversifikasi aset dalam suatu portofolio

\subsection{Capital Assets Pricing Model (CAPM)}

CAPM pertama kali dikembangkan oleh Sharpe (1964) dan Lintner (1965). Mereka mengungkapkan bahwa CAPM merupakan model penetapan harga aktiva ekuilibrium yang mengatakan bahwa return yang diharapkan dari sekuritas tertentu adalah fungsi linear positif dari sensitivitas sekuritas terhadap perubahan portofolio pasarnya. Sensitivitas sekuritas terhadap return pasar inilah yang dilambangkan dengan beta $(\beta)$.

Dalam metode CAPM yang berpengaruh terhadap tingkat pengembalian hanya beta atau risiko sistematis yaitu risiko yang tidak bisa dihilangkan melalui diversifikasi. Model ini mengatakan bahwa expected return adalah hasil dari return sekuritas bebas risiko ditambah dengan premi risiko dikalikan dengan risiko sistematis sekuritas tersebut.

\subsection{Fama-French Model}

\subsubsection{Fama-French Three Factor Model}

Fama dan French (1992) menambahkan dua variabel baru yang mempengaruhi return. Variabel yang ditambahkan adalah size dan book to market ratio. Mereka menemukan bahwa setelah menambahkan dua variabel tersebut, maka secara substansial variasi return saham yang dijelaskan oleh portofolio pasar. Model tiga faktor ini juga menangkap adanya cross section rata-rata return saham di Amerika Serikat.

Fama dan French juga menemukan dalam penelitiannya yaitu BE/ME yang tinggi menandakan laba yang rendah terhadap ekuitas buku. BE/ME yang tinggi memiliki arti bahwa harga saham perusahaan lebih rendah dibandingkan dengan nilai bukunya. Investor pesimis terhadap saham dari perusahaan tersebut.

\subsubsection{Fama-French Five Factor Model}

Fama-French Three Factor Model dianggap belum cukup mampu untuk menjelaskan return. Alhasil Fama dan French melakukan penelitian kembali pada tahun 2014 dengan menggunakan aset sisi kiri (LHS) yang digunakan untuk menguji model lima faktor adalah 
portofolio yang dibentuk berdasarkan size yang dikombinasikan dengan book to market ratio (B/M), profitabilitas (OP) dan investasi (INV).

\subsection{Premi Risiko}

Menurut Brigham dan Houston (2018:366), premi risiko menunjukkan premi yang diminta oleh investor untuk menanggung risiko saham rata-rata. Besarnya premi ini bergantung pada bagaimana pandangan investor terhadap pasar saham dan seberapa tinggi penghindaran risikonya. Pengembalian yang diminta dari saham secara umum dapat dinyatakan sebagai berikut:

Keterangan :

$$
R P_{m}=R_{m}-R_{r f}
$$

$R P_{m} \quad=$ market risk premium

$R_{m} \quad=$ Return pasar

$R_{r f} \quad=$ Pengembalian bebas risiko

\subsection{Size (Ukuran Perusahaan)}

Market Value (MV) adalah ukuran besar kecilnya perusahaan dilihat dari nilai kapitalisasi pasarnya. Kapitalisasi pasar adalah harga jual perusahaan. Rumus untuk menghitung kapitalisasi pasar (Brigham dan Houston, 2018:98) adalah:

Harga saham $x$ Jumlah saham beredar

Menurut Brigham dan Houston (2018:98) nilai kapitalisasi pasar adalah nilai yang mencerminkan kekayaan perusahaan. Ukuran perusahaan juga mempengaruhi kemampuan perusahaan dalam menanggung risiko yang mungkin terjadi dari berbagai kondisi yang dialami oleh perusahaan. Zubir (2011) mengungkapkan bahwa perusahaan berkapitalisasi rendah cenderung memiliki tingkat pengembalian yang tinggi.

\subsection{Book to Market Ratio}

Rasio book to market merupakan perbandingan antara current book value of equity per lembar saham dengan market value per lembar saham (Putra et al., 2019). Rasio ini menunjukkan seberapa jauh perusahaan dapat menciptakan nilai perusahaan relatif terhadap jumlah modal yang diinvestasikan (Brigham dan Houston, 2018:144). Rasio ini juga bisa mengidentifikasi apakah perusahaan tersebut overvalue atau undervalue. Apakah hasil yang didapat dari $\mathrm{B} / \mathrm{M}<1$ maka, saham perusahaan tersebut overvalue. Sedangkan apabila hasil dari $\mathrm{BE} / \mathrm{ME}>1$, maka saham perusahaan tersebut mengalami undervalue. Rumus untuk menentukan book to market ratio adalah

$$
\text { Book to Market ratio }=\frac{\text { Book Value }}{\text { Market Value }}
$$

\subsection{Profitabilitas}

Rasio profitabilitas mengukur kemampuan perusahaan menghasilkan keuntungan pada tingkat penjualan, aset dan modal saham tertentu. Brigham dan Houston (2018:139) mengatakan bahwa rasio profitabilitas mencerminkan hasil akhir dari seluruh kebijakan keuangan dan keputusan operasi perusahaan. 
Rasio profitabilitas yang digunakan adalah ROE (Return On Equity). Rasio ini mengukur kemampuan perusahaan dalam menghasilkan laba berdasarkan modal saham tertentu. Rasio ini adalah yang digunakan investor untuk menilai suatu perusahaan karena ROE mengukur tingkat pengembalian atas investasi pemegang saham biasa. Rumus menghitung besarnya ROE (Brigham dan Houston, 2018:141) adalah

$$
R O E=\frac{\text { Laba neto }}{\text { Ekuitas saham biasa }}
$$

\subsection{Investasi}

Investasi merupakan salah keputusan pendanaan yang dilakukan oleh perusahaan. Investasi yang dilakukan perusahaan bisa dengan cara menambahkan aset perusahaan. Pertumbuhan investasi perusahaan mencerminkan kemampuan perusahaan dalam mengelola pendanaan. Dalam penelitian ini, variabel investasi merupakan tingkat investasi suatu perusahaan yang diukur berdasarkan pertumbuhan total aset (Acaravci \& Karaomer, 2017).

$$
I N V=\frac{\text { Total aset }}{t}_{\text {Total aset }_{t-1}}-1
$$

\subsection{Pengaruh Premi Risiko Terhadap Excess Return}

Premi risiko berbanding lurus dengan market return. Maka semakin besar market return, maka semakin besar pula excess return. Dengan tingginya nilai market return, maka menunjukkan bahwa pasar sedang bullish. Sehingga, investor akan melakukan pengambilan keputusan untuk melakukan investasi pada pasar modal. Semakin banyak yang melakukan investasi, maka permintaan atas suatu saham meningkat, sehingga harga saham akan semakin tinggi. Return yang didapat juga semakin tinggi. Alhasil, excess return yang didapat juga tinggi.

Pada model perhitungan CAPM, Sharpe (1964) mengatakan bahwa risiko pasar yang digambarkan oleh beta ini berpengaruh positif terhadap return. Yang mana berarti semakin tinggi beta, maka semakin sensitif return saham perusahaan tersebut terhadap perubahan yang terjadi di pasar. Perusahaan yang memiliki tingkat risiko pasar yang tinggi berarti harga sahamnya mengikuti aktifitas yang terjadi di pasar saham. Semakin tinggi beta maka volatilitas atau perubahan harga saham juga semakin tinggi. Oleh karena itu investor meminta tambahan return atas kompensasi saham tersebut. Dengan return yang tinggi, maka menghasilkan excess return yang tinggi pula.

Irsyad (2012) dalam penelitiannya menghasilkan bahwa variabel premi risiko berpengaruh terhadap excess return. Begitupun dengan penelitian yang dilakukan oleh Candika (2017) dan Putra, dkk (2019).

H1: Premi risiko berpengaruh positif signifikan terhadap excess return.

\subsection{Pengaruh Size Terhadap Excess Return}

Ukuran perusahaan menggambarkan besar kecilnya perusahaan yang bisa dilihat melalui kapitalisasi pasarnya. Ukuran perusahaan ini berpengaruh positif terhadap excess return. Besar kecilnya perusahaan memengaruhi kemampuan perusahaan tersebut dalam menanggung risiko yang akan dihadapi oleh perusahaan. Perusahaan yang memiliki nilai kapitalisasi yang besar cenderung memiliki risiko yang rendah. Hal ini dikarenakan 
perusahaan besar cenderung memiliki kontrol yang lebih baik terhadap kondisi pasar, sehingga lebih mampu untuk menghadapi persaingan ekonomi. Sehingga investor lebih percaya untuk menginvestasikan dananya kepada perusahaan yang memiliki nilai kapitalisasi yang besar. Dengan meningkatnya permintaan atas saham pada perusahaan yang berkapitalisasi yang besar, maka harga saham akan meningkat menyebabkan return yang didapat juga akan meningkat. Dengan return yang tinggi, maka akan menghasilkan excess return yang tinggi pula.

Banz (1981) menunjukkan bahwa size berpengaruh signifikan dalam menjelaskan return. Penelitian Candika (2017) juga menemukan ukuran perusahaan berpengaruh terhadap excess return. Namun, penelitian yang dilakukan Munawaroh dan Sunarsih (2020) menunjukkan hasil bahwa variabel size tidak berpengaruh signifikan terhadap excess return perusahaan.

H2: Size (ukuran perusahaan) berpengaruh positif signifikan terhadap excess return.

\subsection{Pengaruh Book to Market Ratio Terhadap Excess Return}

Book to market ratio adalah rasio yang digunakan untuk menilai perusahaan berdasarkan nilai pasar sahamnya. Nilai B/M yang tinggi mengindikasikan bahwa investor pesimis dengan perusahaan tersebut sehingga, nilai pasarnya lebih rendah daripada book valuenya. Dengan nilai B/M yang tinggi dan perusahaan mengalami undervalue. Dengan pandangan investor yang pesimis terhadap perusahaan, maka membuat investor enggan untuk membeli saham perusahaan tersebut. Dengan demikian, harga saham akan menurun dikarenakan minimnya permintaan dari investor yang akan membuat return dan excess return akan menurun.

Fama dan French (1995), book to market ratio digunakan untuk melihat kemampuan perusahaan dalam menciptakan nilai perusahaan relatif terhadap jumlah modal yang diinvestasikan. Perusahaan yang memiliki nilai book to market ratio yang tinggi mengindikasikan bahwa perusahaan mengalami distress dan undervalue. Sehingga, investor enggan untuk membeli saham perusahaan yang memiliki nilai rasio $\mathrm{B} / \mathrm{M}$ yang tinggi.

H3: Book to market ratio berpengaruh negatif signifikan terhadap excess return.

\subsection{Pengaruh Profitabilitas Terhadap Excess Return}

Profitabilitas menunjukkan kemampuan perusahaan dalam menghasilkan keuntungan. Perusahaan yang memiliki profitabilitas yang tinggi, maka menghasilkan laba yang tinggi. Sehingga, memiliki risiko likuiditas yang rendah. Hal ini membuat investor tertarik untuk menanamkan modalnya. Dengan banyaknya investor yang melakukan investasi, maka saham perusahaan akan mengalami peningkatan. Sehingga, return akan meningkat dan excess return juga mengalami peningkatan.

Profitabilitas yang digunakan adalah ROE (Return on Equity) dimana menunjukkan penerimaan perusahaan terhadap peluang investasi yang kuat dan pengelolaan biaya yang efektif (Home dan Wachowicz, 2008). Semakin tinggi nilai ROE, maka semakin baik pihak manajemen perusahaan dalam menggunakan modal sendiri. Sehingga, investor akan semakin percaya untuk menanamkan modalnya kepada perusahaan tersebut. 
Arnold (2013) menemukan bahwa profitabilitas berpengaruh positif terhadap return. Begitu pula Putra, dkk (2019), hasil penelitiannya menunjukkan bahwa profitabilitas dan return berpengaruh positif.

H4: Profitabilitas berpengaruh positif signifikan excess return.

\subsection{Pengaruh Investasi Terhadap Excess Return}

Cooper, dkk (2008) menjelaskan bahwa asset growth merupakan prediktor kuat terhadap adanya abnormal return di masa yang akan datang. Perusahaan yang memiliki investasi yang tinggi atau dalam masa pertumbuhan, maka akan membutuhkan dana yang besar. Sehingga, membuat perusahaan menahan mengeluarkan sebagian pendapatannya untuk membayar dividen kepada investor. Hal ini membuat investor kurang tertarik untuk menanamkan modalnya. Dengan begitu, maka return yang didapatkan rendah. Excess return yang diperoleh juga menurun.

H5: Investasi berpengaruh negatif signifikan terhadap excess return.

\section{Metode}

Penelitian ini merupakan penelitian kuantitatif dengan teknik analisis data deskriptif dan model regresi linier berganda. Data yang digunakan adalah data sekunder yang diperoleh dari laporan keuangan perusahaan yang diperoleh dari website masing-masing perusahaan. Populasi dalam penelitian ini adalah seluruh perusahaan yang terdaftar pada LQ 45 tahun 2014-2019. Indeks LQ 45 dipilih dikarenakan perusahaan yang terdaftar pada LQ 45 merupakan perusahaan yang memiliki nilai kapitalisasi pasar yang tinggi serta perusahaanperusahaan yang memiliki kinerja keuangan yang baik dan stabil. Sementara itu, pengambilan sampel menggunakan purposive sampling dengan kriteria sebagai berikut:

Tabel 1. Kriteria Sampel Penelitian

\begin{tabular}{ll}
\hline Kriteria Sampel & Jumlah \\
\hline Perusahaan yang terdaftar di & 65 perusahaan \\
Indeks LQ 45 periode 2014- & \\
2019 & \\
Perusahaan yang berturut-turut & 23 perusahaan \\
terdaftar pada Indeks LQ 45 & \\
periode 2014-2019 & \\
Jumlah sampel akhir & 23 perusahaan \\
\hline
\end{tabular}

Excess return mengukur jumlah dividen tunai yang dibayarkan kepada pemegang saham (Marcus, 2013). Premi risiko mengukur besarnya premi yang diminta oleh investor untuk menanggung risiko saham rata-rata (Marcus, 2013). Ukuran perusahaan adalah nilai yang menunjukkan besar kecilnya ukuran perusahaan (Brigham dan Houston, 2016).

Book to market ratio adalah rasio nilai buku terhadap harga pasar suatu saham (Brigham dan Houston, 2016). ROE adalah rasio yang digunakan untuk mengukur kemampuan perusahaan untuk menghasilkan laba pada tingkat penjualan, aset dan modal saham tertentu (Brigham dan Houston, 2016) dan Investasi adalah tingkat penanaman modal perusahaan yang diukur berdasarkan pertumbuhan total asset (Acaravei dan Karamer, 2017). 
Dalam penelitian ini analisis regresi berganda dilakukan dengan bantuan software SPSS 25.0 dan Microsoft Excel 2016. Sedangkan bentuk persamaan regresi dalam penelitian ini adalah sebagai berikut.

Dimana:

$$
Y=\alpha+\beta_{1} X_{1}+\beta_{2} X_{2}+\beta_{3} X_{3}+\beta_{4} X_{4}+\beta_{5} X_{5}+e
$$

$\mathrm{Y} \quad=$ Excess return

$\alpha \quad=$ Bilangan Konstanta

$\beta_{\mathrm{n}} \quad=$ Koefisien regresi masing-masing variabel

$\mathrm{X}_{1} \quad=$ Premi Risiko

$\mathrm{X}_{2} \quad=$ Size

$\mathrm{X}_{3} \quad=$ Book to Market Ratio

$\mathrm{X}_{4} \quad=$ Profitabilitas

$\mathrm{X}_{5} \quad=$ Investasi

$e \quad=$ error term (tingkat kesalahan dalam penelitian)

\section{Hasil dan Pembahasan}

Tabel 2. Statistika Deskriptif

\begin{tabular}{lllll}
\hline & Min & Max & Mean & StDev \\
\hline $\mathrm{X} 1$ & -.1963 & .1574 & .0156 & .1312 \\
\hline $\mathrm{X} 2$ & 12.9924 & 14.9116 & 13.806 & .4408 \\
\hline $\mathrm{X} 3$ & .0606 & 2.8078 & .5918 & .4786 \\
\hline $\mathrm{X} 4$ & .0349 & 1.3997 & .2009 & .2416 \\
\hline $\mathrm{X} 5$ & -.1084 & 1.4166 & .1568 & .2018 \\
\hline $\mathrm{Y}$ & -.7657 & 2.5503 & .0545 & .4755 \\
\hline
\end{tabular}

Sumber: Data diolah peneliti 2021

Berdasarkan Tabel 2 dapat dilihat bahwa rata-rata premi risiko perusahaan LQ 45 pada tahun 2014-2019 adalah 0,0156 dengan nilai standar deviasi yang menunjukkan penyebaran data nilai premi risiko yaitu sebesar 0,1312 . Hal ini menunjukkan bahwa rata-rata premi yang diminta oleh investor untuk menanggung risiko adalah sebesar $1,56 \%$. Nilai rata-rata kapitalisasi pasar pada perusahaan LQ 45 tahun 2014-2019 adalah 13.833 dengan standar deviasi sebesar 0.4620. Yang artinya rata-rata nilai kekayaan perusahaan LQ 45 adalah 13,833. Nilai rata-rata dari Book to Market Ratio pada perusahaan LQ 45 tahun 2014-2019 adalah 0,5918 dengan nilai standar deviasi sebesar 0,4787 yang artinya harga buku lebih rendah dari harga pasarnya. Sehingga rata-rata mengalami overvalue.

Nilai rata-rata ROE pada perusahaan yang terdaftar pada LQ 45 tahun 2014-2019 adalah 0,2089 atau sebesar $21 \%$ dengan standar deviasi sebesar 0,2489. Sehingga, rata-rata perusahaan LQ 45 mampu menghasilkan laba bersih sebesar 0,21 rupiah tiap 1 rupiah ekuitas saham biasa. . Nilai rata-rata dari tingkat pertumbuhan investasi pada perusahaan LQ 45 tahun 2014-2019 adalah sebesar 0,2009 atau sebesar 20,09\% dengan nilai standar deviasi sebesar 0,2018 . Yang artinya pertumbuhan investasi rata-rata meningkat $20 \%$ tiap tahunnya. Nilai rata-rata dari excess return perusahaan yang terdaftar pada LQ 45 tahun 2014-2019 adalah 0,1568 atau sebesar $15,68 \%$ dengan nilai standar deviasi sebesar 0,4756 
Jurnal Ekonomi, Bisnis dan Pendidikan, 1(5), 2021, 425-438

Tabel 3. Hasil Uji Regresi Linear Berganda

\begin{tabular}{|c|c|c|c|c|c|c|}
\hline \multirow[b]{2}{*}{ Model } & \multicolumn{2}{|c|}{$\begin{array}{l}\text { Unstandardized } \\
\text { Coefficients }\end{array}$} & \multicolumn{2}{|c|}{$\begin{array}{l}\text { Std } \\
\text { Coefficients }\end{array}$} & \multirow[t]{2}{*}{$\mathbf{T}$} & \\
\hline & B & $\begin{array}{l}\text { Std. } \\
\text { Error }\end{array}$ & Beta & & & \\
\hline (Constant) & $\begin{array}{l}- \\
2.02 \\
5\end{array}$ & .911 & & & & .028 \\
\hline $\begin{array}{l}\text { Premi } \\
\text { Risiko }\end{array}$ & .958 & .201 & .385 & & & .000 \\
\hline Size & .153 & .065 & .219 & & & .020 \\
\hline $\mathrm{B} / \mathrm{M}$ ratio & -140 & .066 & -.191 & & & .037 \\
\hline ROE & .233 & .211 & -.094 & & & .271 \\
\hline $\begin{array}{l}\text { Growth } \\
\text { Asset }\end{array}$ & .014 & .188 & .006 & .07 & & .941 \\
\hline
\end{tabular}

Berdasarkan hasil analisis uji regresi pada Tabel 3 premi risiko berpengaruh positif signifikan terhadap excess return pada saham-saham perusahaan yang terdaftar pada Indeks LQ 45 tahun 2014-2019. Hal ini menunjukkan bahwa apabila premi risiko meningkat maka excess return yang akan didapat juga meningkat. Premi risiko berbanding lurus dengan return market. Premi risiko yang tinggi menandakan bahwa return market juga meningkat. Return market yang tinggi menunjukkan bahwa pasar mengalami bullish yang berarti investor dapat mengambil keputusan untuk melakukan investasi pada pasar modal. Oleh karena itu, investor dapat menjadikan premi risiko sebagai indikator untuk mempertimbangkan excess return saham yang selanjutnya dapat digunakan sebagai dasar pengambilan keputusan untuk melakukan investasi.

Premi risiko yang menunjukkan pengaruh signifikan terhadap excess return, maka hasil penelitian ini mendukung konsep dari Capital Assets Pricing Model (CAPM) yang dikembangkan oleh Sharpe (1964) dan Lintner (1965).

Selain itu, terdapat pengaruh positif signifikan antara ukuran perusahaan yang dihitung menggunakan nilai kapitalisasi pasar terhadap excess return pada perusahaan LQ 45 tahun 2014-2019. Kapitalisasi pasar menunjukkan harga jual perusahaan. Tingginya kapitalisasi pasar suatu perusahaan berarti harga saham dan jumlah saham yang beredar juga tinggi. Semakin meningkatnya nilai harga saham membuat investor tertarik untuk menanamkan modalnya dikarenakan return yang didapat juga akan meningkat.

Hasil penelitian ini mendukung penelitian yang dilakukan oleh Putra, dkk (2019) bahwa variabel ukuran perusahaan berpengaruh positif signifikan terhadap excess return pada perusahaan yang terdaftar pada LQ 45 tahun 2014-2018. Banz (1981), Fama dan French (2015), Sutrisna dan Ekaputra (2015), Candika (2017) juga menunjukkan hasil yang sama yaitu ukuran perusahaan berpengaruh positif signifikan terhadap excess return.

Nilai rasio Book to Market berpengaruh negatif signifikan terhadap excess return pada perusahaan LQ 45 tahun 2014-2019. Hal ini berarti perusahaan yang memiliki rasio B/M yang tinggi cenderung memiliki excess return yang rendah. Tingginya rasio B/M menunjukkan 
bahwa nilai pasar lebih rendah dari pada nilai bukunya. Hal ini menandakan bahwa perusahaan mengalami undervalue.

Tingginya rasio book to market menunjukkan bahwa investor pesimis dengan kinerja perusahaan tersebut. Meningkatnya rasio B/M juga membuat investor enggan untuk membeli saham perusahaan tersebut. Dengan menurunnya permintaan dari investor, maka harga saham akan menurun yang membuat return juga menurun. Semakin rendah return yang didapat, maka excess return yang didapat juga akan menurun. Sehingga, rasio Book to Market berpengaruh negatif terhadap excess return.

Hasil penelitian ini tidak sesuai dengan penelitian yang dilakukan Putra, dkk (2019). Putra, dkk (2019) menemukan bahwa Book to Market Ratio berpengaruh positif terhadap excess return perusahaan LQ 45 tahun 2014-2018.

Sedangkan, profitabilitas yang diukur melalui Return on Equity (ROE) tidak berpengaruh terhadap excess return pada perusahaan LQ 45 tahun 2014-2019. Tidak berpengaruhnya ROE terhadap excess return pada perusahaan LQ 45 dikarenakan sebagian besar investor yang melakukan investasi pada saham perusahaan LQ 45 merupakan investor jangka pendek yang lebih tertarik dengan capital gain daripada pendapatan jangka panjang yaitu dividen.

Ketika investor lebih tertarik dengan capital gain atau selisih dari harga jual dengan harga beli. Maka, investor tidak mempertimbangkan ROE dalam melakukan keputusan pembelian saham. Namun, ketika investor lebih tertarik pada dividen, maka harus mempertimbangkan ROE. Dikarenakan, tingginya nilai ROE maka akan menghasilkan dividen yang tinggi.

Hasil penelitian ini konsisten dengan penelitian yang dilakukan Sutrisna dan Ekaputra (2016) yang menunjukkan bahwa profitabilitas memiliki pengaruh yang lemah terhadap return di pasar modal Indonesia pada tahun 2000-2015.

Begitu pula dengan tingkat pertumbuhan investasi tidak berpengaruh terhadap excess return pada perusahaan LQ 45 tahun 2014-2019. Hal ini dikarenakan tingkat kapitalisasi yang tinggi yang diperoleh oleh perusahaan LQ 45, maka perusahaan tidak menambah investasi pada aset tetap. Apabila perusahaan memiliki growth asset yang tinggi, maka kebutuhan dana akan meningkat dan perusahaan akan memilih untuk menahan laba daripada harus dibagikan sebagai dividen. Hal ini membuat investor kurang tertarik untuk melakukan investasi pada perusahaan yang memiliki growth asset yang tinggi.

Hasil ini didukung oleh penelitian yang dilakukan Sutrisna dan Ekaputra (2016), Mischenko, Naumenkova dan Paltienko (2020) yang menyatakan bahwa investasi berpengaruh tidak signifikan terhadap excess return

\section{Simpulan}

\subsection{Kesimpulan}

Hasil penelitian yang dilakukan menunjukan bahwa Fama-French Five Factor Model berpengaruh secara simultan terhadap excess return pada perusahaan LQ 45 tahun 2014-2019. 
Sedangkan, secara parsial hanya variabel premi risiko, ukuran perusahaan dan book to market ratio yang memiliki pengaruh terhadap excess return. Dari ketiga variabel tersebut, variabel premi risiko memiliki pengaruh yang paling besar terhadap excess return.

\subsection{Saran}

Dikarenakan pada penelitian ini menggunakan penyederhanaan proxy, maka peneliti selanjutnya bisa menggunakan cara berpikir dan mekanisme yang sesuai dengan rujukan utama. Selanjutnya jika dilihat berdasarkan koefisien determinasi yang cenderung cukup rendah maka, bagi peneliti selanjutnya yang tertarik pada topik penelitian ini dapat menambahkan variabel lain seperti Debt Equity Ratio (DER), Earning Per Share (EPS) atau mengganti proksi ROE menjadi ROA.

Peneliti juga menyarankan menggunakan asset pricing model lainnya seperti Capital Asset Pricing Model (CAPM) yang mempertimbangkan market risk. Peneliti juga bisa menggunakan Arbitrage Pricing Theory (APT) yang mempertimbangkan risiko dari variabel makro yang tidak terbatas. Hal ini dimaksudkan agar ditemukan model yang dapat memprediksi excess return dengan lebih akurat. Peneliti juga bisa menambahkan indeks lain atau bahkan menggunakan populasi seluruh perusahaan yang terdaftar pada Bursa Efek Indonesia dengan rentang waktu yang lebih lama. Mengingat penelitian ini hanya menggunakan satu indeks saja yaitu LQ 45 dan hanya menggunakan rentang waktu enam tahun.

\section{Daftar Rujukan}

Acaravci, S. K., \& Karaomer, Y. (2017). International Journal of Economics and Financial Issues Fama-French Five Factor Model: Evidence from Turkey *. International Journal of Economics and Financial Issues, 7(6), 130-137. (http:www.econjournals.com), (Online) diakses pada 12 September 2020

Arnold, T. M. (2013). The Other Side of Value: The Gross Profitability Premium. CFA Digest, 43(2), 105-107 (Online). (https://doi.org/10.2469/dig.v43.n2.56) di akses pada 6 Oktober 2020

Ashgarian, H dan Hansson. (1998) Cross Sectional Analysis Of The Swedish. (Online) diakses pada 14 September 2020 diakses pada 14 September 2020

Brigham, F. Eugene \& Houston, Joel F. (2018). Dasar-Dasar Manajemen Keuangan Buku 1 Edisi 14. Jakarta: Salemba Empat.

Brigham, F. Eugene dan Houston. (2004) Financial Management, Edisi 10, Jilid 1. Jakarta: Salemba Empat.

Banz, R. W. (1981). The relationship between return and market value of common stocks. Journal of financial economics, 9(1), 3-18. diakses pada 14 September 2020

Basu, S. (1977). Investment performance of common stocks in relation to their price-earnings ratios: A test of the efficient market hypothesis. The Journal of Finance, 32(3), 663-682. diakses pada 14 September 2020

Candika, Y. I. (2017). Pengujian kekuatan model carhart empat faktor terhadap excess return saham di indonesia. The Indonesian Journal of Applied Business, 1(1), 14-29. diakses pada 16 September 2020

Cox, S., \& Britten, J. (2019). The Fama-French five-factor model: evidence from the Johannesburg Stock Exchange. Investment Analysts Journal, 48(3), 240-261. (https://doi.org/10.1080/10293523.2019.1647982) diakses pada 18 September 2020

Dirkx, P., \& Peter, F. J. (2018). Implementing the Fama-French Five-Factor Model for the German Stock Market. Available at SSRN 3300642. (https://doi.org/10.2139/ssrn.3300642) diakses pada 7 Oktober 2020

Djamaluddin, S., \& Rofii, A. (2017). Fama and French Five-Factors Pricing Model Testing in Indonesia. International Journal of Business and Management Invention ISSN, 6(9), 75-90. (www.ijbmi.org75\%7C) diakses pada 9 September 2020 
Fama, E. F., \& French, K. R. (2015). A five-factor asset pricing model. Journal of Financial Economics 116, 1-22. diakses pada 10 September 2020

Fama, E. F., \& French, K. R. (1995). Size and Book-to-Market Factors in Earnings and Returns. The Journal of Finance, 50(1), 131-155. (https://doi.org/10.1111/j.1540-6261.1995.tb05169.x), diakses pada 10 September 2020

Fama, F., \& French, R. (2001). Fama_French_1993_Jfe. 33, 1-54. (https://doi.org/10.1016/0304405X(93)90023-5), diakses pada 11 September 2020

Foye, James. (2016). A New Perspective on The Size, Value, and Momentum Effects: Broad Sample Evidence from Europe. Review of Accounting and Finance, Vol. 15 Iss 2, (https://www.emerald.com/insight/content/doi/10.1108/RAF-05-2015-0065/full/html), diakses pada 14 September 2020

Hodoshima, J. Garza, G.X. \& Kimura, M, (2000). Cross Sectional Analysis of Return and Beta in Japan. Journal Economic and Business, 515-553, (https://doi.org/10.1016/S0148-6195(00)00031-X), diakses pada 12 September 2020

Huang, Z. (2016). Are Profitability and Investment Good Proxies for Risk Factors the Analysis on Fama and French's Five-Factor Model. In 3rd International Conference on Management Science and Management Innovation (MSMI), 200-203. (https://doi.org/10.2991/msmi-16.2016.48), diakses pada 15 Oktober 2020

Ika Ardina Putri, N., \& Ayu Diantini, N. (2016). Analisis Penilaian Pasar Terhadap Return Saham Pada Industri Barang Konsumsi. E-Jurnal Manajemen Universitas Udayana, 5(8), 243760. diakses pada 14 September 2020

Kasmir. (2010). Pengantar Manajemen Keuangan. Jakarta: Kencana

Keuangan, O. J. (2014). Undang-Undang Republik Indonesia Nomor 8 Tahun 1995 Tentang Pasar Modal. (https://www.ojk.go.id), diakses 12 September 2020.

Komara, Esi Fitriani, et al. (2015). Analisis Three Factor Fama and French Model Terhadap Return Pada Indeks Saham Syariah Indonesia (ISSI) Periode 2011-2014. Jurnal Inspirasi Bisnis Dan Manajemen, vol. 3, no. 2, 2020, p. 105, (https://doi.org/10.33603/jibm.v3i2.2554), diakses pada 14 September 2020

Kubota, K. and Takehara, H. (2017). Does the Fama and French Five-Factor Model Work Well in Japan? International Review of Finance, 18(1), pp.137-146, (https://www.semanticscholar.org), diakses pada 14 September 2020

Lintner, J. (1969). The Valuation of Risk Assets and the Selection of Risky Investments in Stock Portfolios and Capital Budgets: A Reply. The Review of Economics and Statistics, 51(2), 222. (https://doi.org/10.2307/1926735), diakses pada 10 September 2020

Munawaroh, U., \& Sunarsih, S. (2020). The effects of Fama-French five factor and momentum factor on Islamic stock portfolio excess return listed in ISSI. Jurnal Ekonomi \& Keuangan Islam, 6(2), 119-133. (https://doi.org/10.20885/jeki.vol6.iss2.art4), diakses pada 14 September 2020

Naufal, H. (2014). Manajemen Keuangan: Berbasis Balanced Scorecard: Pendekatan Teori, Kasus, dan Riset Bisnis. Jakarta: Bumi Aksara.

Ozkan, N. (2018). Fama-French Five Factor Model and The Necessity of Value Factor: Evidence from Istanbul Stock Exchange. Pressacademia, 8(1), 14-17. (https://doi.org/10.17261/pressacademia.2018.972) diakses pada 20 September 2020

Paliienko, O., Naumenkova, S., \& Mishchenko, S. (2020). An empirical investigation of the Fama-French fivefactor model. Investment Management and Financial Innovations, 17(1), 143-155. (https://doi.org/10.21511/imfi.17(1).2020.13), (Online) diakses pada 25 September 2020

Prihadi, T. (2013). Analisis laporan Keuangan (Edisi 3). Jakarta: PPM.

Putra, I. G. S., Susanti, N., \& Putra, O. E. (2019). Pengujian Fama \& French Five-Factors Asset Pricing Model Pada Indeks Lq 45 Periode 2014-2018. Bisma, 13(3), 148. (https://doi.org/10.19184/bisma.v13i3.10981), diakses pada 15 September 2020

Racicot, F. E., \& Rentz, W. F. (2016). Testing Fama-French's New Five-Factor Asset Pricing Model: Evidence From Robust Instruments. Applied Economics Letters, 23(6), 444-448. (https://doi.org/10.1080/13504851.2015.1080798), diakses pada 14 Oktober 2020 
Ragab, N. S., Abdou, R. K., \& Sakr, A. M. (2019). A Comparative Study between the Fama and French ThreeFactor Model and the Fama and French Five-Factor Model: Evidence from the Egyptian Stock Market. International Journal of Economics and Finance, 12(1), 52. (https://doi.org/10.5539/ijef.v12n1p52), diakses pada 15 Oktober 2020

Richey, G. (2017), Fewer Reasons to Sin: A Five-Factor Investigation of Vice Stock Returns: Managerial Finance, Vol. 43(9), pp. 1016 1033, (https://doi.org/10.1108/MF-09-2016-0268), diakses pada 15 September 2020

Sharpe, W. F. (1964). A Theory of Market Equilibrium under Conditions of Risk. The Journal of Finance, 19(3), 425-442., diakses pada 11 September 2020

Sudiyatno, B., \& Irsyad, M. (2011). Study of The Three Factor Model Fama and French in Indonesia Stock Exchange. Jurnal Bisinis Dan Ekonomi (JEB), 18(2), 126-136. diakses pada 14 September 2020

Sugiyono. (2010). Statistika Untuk Penelitian. Bandung: Alfabeta

Sujarweni, V. Wiratna. (2015). Metodologi Penelitian Bisnis Ekonomi. Yogyakarta: Pustaka baru press

Sutrisno, B., \& Ekaputra, I. A. (2016). Uji Empiris Model Asset Pricing Lima Faktor Fama-French Di Indonesia. Jurnal Keuangan Dan Perbankan, 20(3), 343-357.. diakses pada 14 September 2020

Tandelilin, Eduardus. (2010). Portofolio dan Investasi Teori dan Aplikasi Edisi Pertama. Yogyakarta: Kanisius

Zaremba, A., \& Czapkiewicz, A. (2017). Digesting Anomalies In Emerging European Markets: A Comparison Of Factor Pricing Models. Emerging Markets Review, 31, 1-15. (https://doi.org/10.1016/j.ememar.2016.12.002) (Online) diakses pada 14 September 2020

Zubir, Z. (2011). Manajemen portofolio: penerapannya dalam investasi saham. Jakarta: Salemba Empat. 